IZA DP No. 5746

Beyond Additionality: Are Innovation Subsidies Counterproductive?

Alessandra Catozzella Marco Vivarelli

May 2011 


\title{
Beyond Additionality: Are Innovation Subsidies Counterproductive?
}

\author{
Alessandra Catozzella \\ Università Cattolica del Sacro Cuore \\ Marco Vivarelli \\ Università Cattolica del Sacro Cuore, \\ SPRU, University of Sussex and IZA
}

Discussion Paper No. 5746

May 2011

IZA

P.O. Box 7240

53072 Bonn

Germany

Phone: +49-228-3894-0

Fax: +49-228-3894-180

E-mail: iza@iza.org

Any opinions expressed here are those of the author(s) and not those of IZA. Research published in this series may include views on policy, but the institute itself takes no institutional policy positions.

The Institute for the Study of Labor (IZA) in Bonn is a local and virtual international research center and a place of communication between science, politics and business. IZA is an independent nonprofit organization supported by Deutsche Post Foundation. The center is associated with the University of Bonn and offers a stimulating research environment through its international network, workshops and conferences, data service, project support, research visits and doctoral program. IZA engages in (i) original and internationally competitive research in all fields of labor economics, (ii) development of policy concepts, and (iii) dissemination of research results and concepts to the interested public.

IZA Discussion Papers often represent preliminary work and are circulated to encourage discussion. Citation of such a paper should account for its provisional character. A revised version may be available directly from the author. 


\section{ABSTRACT \\ Beyond Additionality: Are Innovation Subsidies Counterproductive?*}

Building on a standard policy evaluation literature mainly aimed at estimating the additional effect of subsidies on either firms' innovative expenditures or innovative outputs only, this paper tries to move one step further, combining the two (input and output) dimensions of innovation into a unique efficiency perspective. To this aim, the impact of public funding on the ratio between innovative sales and innovative expenditures (innovative productivity) is estimated using a sample of firm-level data drawn from the third Italian Community Innovation Survey (CIS). A bivariate endogenous switching model has been developed in order to free the analysis of any ex ante sources of sample selection and firm heterogeneity, at the same time getting rid of the two sources of endogeneity potentially affecting the results, i.e. the possible simultaneity between subsidy allocation and the qualitative composition of the innovative output, as well as the endogeneity of public support with respect to innovative performance. Results show that innovative productivity is negatively affected by the innovation subsidy; far from 'doing better' as a result of government intervention, supported firms appear to exhaust their advantage through merely increasing their innovative expenditures.

JEL Classification: $\quad$ O32, O38

Keywords: innovation subsidy, policy evaluation, product innovation, bivariate endogenous switching model

Corresponding author:

Marco Vivarelli

Facoltà di Economia

Università Cattolica del Sacro Cuore

Via Emilia Parmense 84

I-29122 Piacenza

Italy

E-mail: marco.vivarelli@unicatt.it

\footnotetext{
* The authors would like to thank the Adele Laboratory at ISTAT in Rome for the provision of the CIS data.
} 


\section{Introduction}

Government intervention supporting private innovative activities is now a common practice in all OECD countries, justified on the grounds that under-investment in innovation by leading profit-maximising firms is the result of market failures. However, despite the wide diffusion of government intervention programs, there is still little consensus regarding their true effectiveness in spurring innovation; indeed, while theoretical arguments can be invoked to support the possibility of both a positive and a negative (relative ${ }^{1}$ ) impact of government intervention on firms' innovative activity (Garcia-Quevedo, 2004), empirical studies do not clearly discriminate between them ${ }^{2}$. In fact, the sign and magnitude of the public support effect turns out to be highly influenced by the econometric specification adopted in each study to deal with the possible endogeneity of government intervention with respect to firms' innovative performances: are firms doing better because they have received public support, or have they received public support because they were already doing better?

A deeper understanding of the funding allocation process and its interaction with the effects the funding itself produces would be helpful in answering this question; up to now, however, political interests seem to have driven the analysis mainly towards the issue of additionality $^{3}$, neglecting both the importance of the allocation process and the possibility that such input-side additionality does not translate into proportionally higher innovative outputs. The latter point, in particular, seems to deserve deeper investigation: although the additionality of the government intervention with respect to privately-funded innovative activities can be verified, an efficiency loss can still occur because of a lack of proportionality between the effect of public support on firms' innovative expenditure and its final impact in terms of innovative output.

Therefore, starting from standard evaluation literature which is mainly aimed at estimating the effect of public funding on either firms' innovative expenditure or their innovative output only (see Section 2 for a review of this literature), this work tries to move one step further, combining the two (input and output) dimensions of innovation in a unique

\footnotetext{
${ }^{1}$ Relative to what the firms (taken both individually and in aggregate) would have done had they not received any public support.

${ }^{2}$ See Capron and Van Pottelsbergue (1997) for an overview of this empirical literature.

${ }^{3}$ e.g. by assessing whether an R\&D subsidy involves additional R\&D expenditures by the receiving firm.
} 
efficiency perspective, allowing us to test the proportionality between them. To this end, the impact of public funding on the ratio between total innovative sales and total innovative expenditures, considered as a measure of innovative productivity, is investigated. This change of perspective is a response to the need for evaluation of whether supported firms are really doing better, not just more, than non-supported ones, 'doing better' having more to do with the efficient use of innovative inputs rather than with the absolute value of the innovative expenditures. The definition of this productivity variable, together with the description of data and indicators used in the empirical analysis, can be found in Section 3, in which initial descriptive analysis is provided, and the idea of a possible efficiency loss being associated with public support is put forward. In order for this result to be tested, a bivariate-switching model has been developed (Section 4), the main novelty of which consists in getting rid of both selection bias and endogeneity of the treatment (funding) variable, while at the same time checking for possible simultaneity. Econometric results, strongly confirming initial descriptive evidence pointing to an efficiency loss, are presented and discussed in Section 5, while Section 6 briefly concludes.

\section{Previous literature}

The rationale for public intervention in supporting private innovative activities mainly rests on the likely occurrence of two market failures. Firstly, capital market imperfections exist, making it excessively costly or difficult for the firm to access external financing sources. The strong asymmetry between entrepreneurs' and financiers' information about the quality of an innovative project (as well as about the quality of the firm itself in many cases) leads to a higher cost of external capital, often preventing firms with no internal funds from undertaking projects with positive net present value (Leland and Pyle, 1977; Hall, 1991). The second failure dates back to Arrow's (1962) argument that knowledge is a non-rival good; the impossibility of appropriating all the benefits arising from innovation makes social marginal returns on new knowledge higher than private ones. Griliches (1992) and Hall (1996) provide robust empirical evidence in this direction. In the absence of government intervention, such 
market failures would lead to the underprovision of innovative activities with respect to the social optimum; of course, the risk always exists that the potential positive effects generated by government intervention are completely thwarted by deadweight or substitution effects, supporting firms that did not need any help since they would have invested anyway (deadweight effect) or sustaining inefficient firms at the expense of more efficient ones (substitution effect).

On theoretical grounds then, both an optimistic and a sceptical view of innovation subsidies can be supported; however, up to now and to our knowledge, empirical evidence does not seem to have provided a definite answer to this debate. Although in absolute terms public funding appears to foster both the input and the output sides of innovation, a crowding out effect also seems to operate, totally or partially displacing privately-funded innovation activities $^{4}$. For instance, using a dataset of firms which benefited from the Small Business Innovation Research Program, Wallsten (2000) comes to the conclusion that R\&D grants completely crowd out firm-financed R\&D spending, dollar for dollar. Much more optimistic is the view of Gonzales et al. (2005), who found no evidence of crowding out: using an unbalanced panel of more than 2,000 Spanish manufacturing firms, the authors show government intervention as stimulating $R \& D$ activities (up to the point that without such support some firms would even stop performing innovation). Midway between such extreme results, the majority of existing empirical literature on the subject shows that public support is indeed fostering innovation, with crowding out effects operating only partially (see Busom, 2000). In particular, previous studies (see Capron and Van Pottelsbergue, 1997) show that the magnitude of the crowding out depends on factors such as: 1) the level of aggregation of the analysis (a positive effect of public support is seen much more clearly at the industry than at the firm level); 2) the adopted econometric methodology; 3 ) the size of the investigated firms 5 and 4) the geographical area considered.

Most of these studies, however, do not depart from the standard additionality issue: does public support really add to what the subsidised firm would have invested had it not taken part in a policy program? What this literature seems to neglect is the final impact of

\footnotetext{
${ }^{4}$ Cohen and Noll (1991) go as far as to say that politicians face incentives to use technology programs to reward constituents, not to correct market failures.

${ }^{5}$ Lach (2002), for example, finds that small firms enjoy positive dynamic total effects from a subsidy, which seem to fade away as soon as large firms are considered.
} 
government intervention on firms' innovative performance: does the (possibly) higher input level induced by public support lead to a correspondingly higher innovative performance in terms of input-output efficiency?

Czarnitzki (2002) rightly raises this question, without fully addressing it. Bérubé and Mohnen (2009) deal with it partially, exploring the impact that government intervention has on alternative measures of innovative output. However, the input dimension is not taken into account, thus making it impossible to figure out which fraction of the innovative output increase is due merely to an indirect effect of higher innovative inputs induced by public support, and which part, instead, reflects a direct impact of government intervention on firms' innovative productivity. An interesting step in this direction has been taken by Garcia and Mohnen (2010): using cross-sectional firm-level data taken from the third Austrian CIS, the authors show how no (significant) direct effect of government intervention on the share of innovative turnover emerges once the indirect effect of a higher level of $R \& D$ expenditures has been accounted for $^{6}$. However, while allowing for a different intercept to characterize the supported and non-supported sub-samples, the authors do not explicitly investigate the possibility that public funding also affects the marginal effect of R\&D on innovative output. Once again, the study is limited to an evaluation of whether supported firms are doing more, not whether they are doing better, than the non-supported ones. Overall, the efficiency impact of government intervention emerges as a necessary complement to the additionality issue and deserves further investigation.

\section{Dataset, sample selection and descriptive statistics}

Empirical analysis investigating the impact government intervention may have on innovative productivity has been carried out using firm-level data drawn from the third Italian Community Innovation Survey (CIS 3) conducted over a three-year period (1998-2000) by the Italian National Institute of Statistics (ISTAT). A 53\% response rate determined the full

\footnotetext{
${ }^{6}$ See also Branstetter and Sakakibara (1998).
} 
sample size of $15,512^{7}$ firms. We focus on 9,034 of them, those belonging to the manufacturing sector. Once cleaned of outliers and firms which were either newborn or had recorded an output variation of at least $10 \%$ due to $\mathrm{M} \& \mathrm{~A}$, the adopted sub-sample was of 7,965 observations.

The dataset comprises a set of general information (main industry of affiliation, group belonging, sales, employment, export sales) together with a much larger set of innovation variables measuring firms' innovativeness, economic and non-economic effects of innovation, subjective evaluations of factors hampering or fostering innovation, information sources, participation in cooperative innovation activities and access to public funding ${ }^{8}$. In particular, firms were asked to answer the question "Has your enterprise received any kind of public support for innovation-related activities in the last three years?". A note to the question specifies that in contrast with other CIS (such as the UK CIS which also included nonfinancial forms of assistance), only financial support is to be considered, including contributions in capital or interest accounts, facilitated funding, tax credits and fiscal bonuses. No distinction is made between the different forms of support, and no further classification is introduced which would have enabled us to identify the specific innovative input (or output) the government's programs aimed at supporting.

We can thus introduce a generic public-support dummy variable (funding), equal to 1 if a given innovative firm received some kind of financial support to innovation, and equal to 0 otherwise. It is important to underline some aspects concerning the funding variable constructed in this way. The filter-based nature of the CIS questionnaire requires firms to answer the full set of innovative questions, including the one concerning funding, only if they have either started innovative projects (then abandoned or still to be completed) or introduced innovation outputs. As a consequence, our empirical analysis is limited to investigating the efficiency impact of public funding within a sample of innovative firms, while we are unable to consider its role in making a firm innovative. Moreover, since we are interested in investigating innovative input-output efficiency, we further limit our attention to the firms

\footnotetext{
${ }^{7}$ Thanks to a weighting procedure assigning weights according to the reciprocal of the probability of each observation being sampled, this sample is representative, at both sector and firm size level, of the entire population of Italian firms with more than 10 employees.

${ }^{8}$ Italian CIS data have been used for a variety of empirical investigations, including the test of the "knowledge production function" (see Conte and Vivarelli, 2005) and the determinants of R\&D cooperative agreements (see, for example, Piga and Vivarelli, 2003).
} 
which have declared they invested both in innovative inputs and innovative outputs, i.e. firms that in the past three years have introduced product or process innovations or started innovative projects then abandoned or still to be completed as of December $31^{\text {st }}, 2000$. Therefore, our sample reduces to 2,855 innovative firms, generating an obvious problem of sample selection that we have to bear in mind when dealing with our core question: are the firms that received public support (funding=1) 'doing better' than those which did not get access to public funding (funding=0)? In this framework, a first necessary step is that of defining an adequate measure of innovative performance: what do we really mean by 'doing better'?

\subsection{Innovative productivity}

As highlighted in Section 2, most policy evaluation literature focuses on just the inputor the output-side effect of funding, investigating either the impact of public support on firms' $\mathrm{R} \& \mathrm{D}$ expenditure levels (input side), or its effect on measures of innovative output, such as the number of patents or the share of total sales due to innovative products. However:

1. the public funding measure provided by the Italian CIS is a generic indicator of financial assistance, not specifically related to a single input (which would be the case, for instance, of $R \& D$ tax credits). It follows that adopting $R \& D$ expenditures as the only benchmark for the funding effect would only capture a partial effect, neglecting any potential impact on other innovative inputs also measured by CIS, such as expenditures for buying innovative machineries or external knowledge (licences). Therefore, in this study we consider as innovative input the firm's overall expenditures for internal and external R\&D activities as well as for technological acquisition;

2. as discussed in Section 2, the impact of funding on innovative output is the joint result of an indirect effect through the increase in firms' innovative inputs and a possible direct effect on their innovative productivity. Therefore, a simultaneous analysis of both the innovative inputs and outputs is carried out in order to test the actual impact of a public subsidy. 
With the purpose of simultaneously addressing these two issues, the impact of public funding on the ratio between total innovative sales and total innovative expenditures is explored. From now on, this ratio will be referred to as our innovative productivity variable (pdtv), measuring how many $€$ s of innovative sales (i.e. sales due to innovative products) a firm realizes for each $€$ spent on innovative inputs. Adopting a productivity measure fully matches our aim, which is not to evaluate whether subsidized firms invest more in innovation, but whether they are more efficient in transforming innovative inputs into innovative outputs.

\subsection{Further selection and descriptive statistics}

One of the main limitations of CIS is that the only continuous measure of innovative output is turnover due to innovative products (turninn), which is used to construct our key productivity variable pdtv. This limitation further reduces the extent of our analysis from the 2,855 firms engaged in process and/or product innovation to the sub-sample of firms reporting product innovations only (746 observations). Because a continuous output measure of process innovation is not available in the adopted dataset, firms engaged in this form of innovation have to be excluded, otherwise the observed effect of funding on pdtv would be biased either downward (in the case of firms reporting process innovation only, the innovative productivity of which would be zero) or unpredictably downward/upward, in accordance with the effect of the subsidy on the qualitative composition of the innovation output (this is the case of firms declaring they had introduced both product and process innovations) ${ }^{9}$. Since no data are available on either the nature of the subsidy or the distribution of total innovative expenditures between product and process innovation, we have to restrict our analysis to the sub-sample of

\footnotetext{
${ }^{9}$ In particular, if the subsidy is designed to favour product- at the expense of process-innovation, then an upward bias affects its estimated impact on pdtv, the higher share of innovative turnover being, at least in part, due to a qualitative effect and not to a higher efficiency in transforming innovative inputs into outputs. On the other hand, whenever process-oriented public support is implemented, a downward bias occurs, since part of the lower innovative turnover is due to a composition effect encouraging firms to devote a larger fraction of their total innovative expenditures to process innovation, which is not accounted for in the productivity measure we have adopted.
} 
746 product-only innovators ${ }^{10}$. Of these, 389 firms $(52.14 \%)^{11}$ declared they had received some kind of public financial support (i.e. were 'treated') during the previous three years, while the remaining 357 observations (47.86\%) were not supported ('non-treated').

A preliminary, descriptive comparison of these two sub-samples is provided below (Table 1), showing the quantitative (unconditional) effect that the subsidy produces on: 1) the share of turnover due to innovative sales (turninn $(\%)=$ sales from new products/total sales); 2 ) the total innovative expenditure intensity (tot_inn intensity $(\%)=$ total innovative expenditures/ total sales); and 3) the productivity measure we obtain upon dividing the first measure by the second $(\mathrm{pdtv}=$ sales due to new products / total innovation expenditures).

\section{Table 1: Descriptive statistics.}

\begin{tabular}{|c|c|c|c|c|c|}
\hline & \multicolumn{3}{|c|}{ Sample means } & \multicolumn{2}{|c|}{ Mean differences } \\
\hline & $\begin{array}{c}\text { All } \\
\text { firms } \\
N=746\end{array}$ & $\begin{array}{l}\text { Non-supported } \\
\text { firms } \mathrm{N}_{0}=357\end{array}$ & $\begin{array}{c}\text { Supported } \\
\text { firms } N_{1}=389\end{array}$ & $\begin{array}{c}\text { Difference: } \\
\text { mean }\left(N_{1}\right)- \\
\operatorname{mean}\left(N_{0}\right)\end{array}$ & $\begin{array}{c}\% \text { Difference: } \\
\text { mean }\left(N_{1}\right)- \\
\text { mean }\left(N_{0}\right)\end{array}$ \\
\hline Turninn (\%) & 26.474 & 23.871 & 28.864 & $\begin{array}{l}4.993^{\star *} \\
(0.011)\end{array}$ & $+20.91 \%$ \\
\hline $\begin{array}{l}\text { tot_inn } \\
\text { intensity (\%) }\end{array}$ & 4.802 & 3.95 & 5.584 & $\begin{array}{l}1.633^{\star *} \\
(0.002)\end{array}$ & $+41.35 \%$ \\
\hline pdtv $^{12}$ & 10.938 & 11.86 & 10.09 & $\begin{array}{l}-1.771^{*} \\
(0.081)\end{array}$ & $-14.93 \%$ \\
\hline
\end{tabular}

Notes:

- in the case of tot_inn intensity and pdtv, two-sample t-tests with unequal variances were computed, since the null of equal variances was rejected by Bartlett's test for equal variances;

- p-values in brackets: ${ }^{* * *}=1 \%$ significant; ${ }^{* *}=5 \%$ significant; ${ }^{*}=10 \%$ significant

${ }^{10}$ A parallel analysis was performed using the (larger but mixed) sample of the 2,198 firms realising either product only or product and process innovation, thus only excluding firms that engaged in process innovations solely; the results are very similar to those discussed in Section 5 and are available upon request.

${ }^{11}$ Such a high share of supported firms in the total is explained by the selection of innovative firms only.

${ }^{12}$ It must be noticed that:

$$
\operatorname{Avg}\left(\operatorname{pdtv}_{\mathrm{i}}\right)=\operatorname{Avg}\left(\frac{\text { tot_inn_expenditure }_{i}}{\text { turninn }_{i}}\right)=\text { average of the ratios }
$$

Therefore, the pdtv values shown in table 1 (third row) are not equal to the ratio between the two averages reported in the two rows above. 
Then the mean differences in the three innovation measures between supported and non-supported firms, the so-called 'treatment-control comparison', were computed. These differences, which provide us with preliminary estimates of the effects generated by the subsidy, are reported in the last two columns of Table 1, together with the corresponding pvalues from the two-sample t-tests of their significance.

In spite of the positive impact of the subsidy on both turninn and tot_inn intensity (supporting 'additionality' as conventionally defined), a negative (barely significant) effect emerges when innovative productivity is considered, pdtv shrinking by almost 15 percentage points from the non-supported to the supported sub-sample. Such an efficiency loss in firms' ability to transform innovative inputs into innovative outputs clearly emerges from Figure 1, which shows the linear regression lines with the corresponding 95\% confidence bands, from the regressions of the logarithmic of sales from new products (turninn) to the logarithmic of total innovative expenditures (tot_exp) in the two sub-samples. Although the output level is higher in the subsidized sample, the slope measuring the elasticity of the turnover due to innovative sales to the total innovative expenditures turns out to be much lower when supported firms are considered (black line in Figure 1).

\section{Figure 1: Linear predictions and $95 \%$ confidence bands from the regression of $\log$ (turninn) on $\log ($ tot_exp) in the two sub-samples identified by funding}

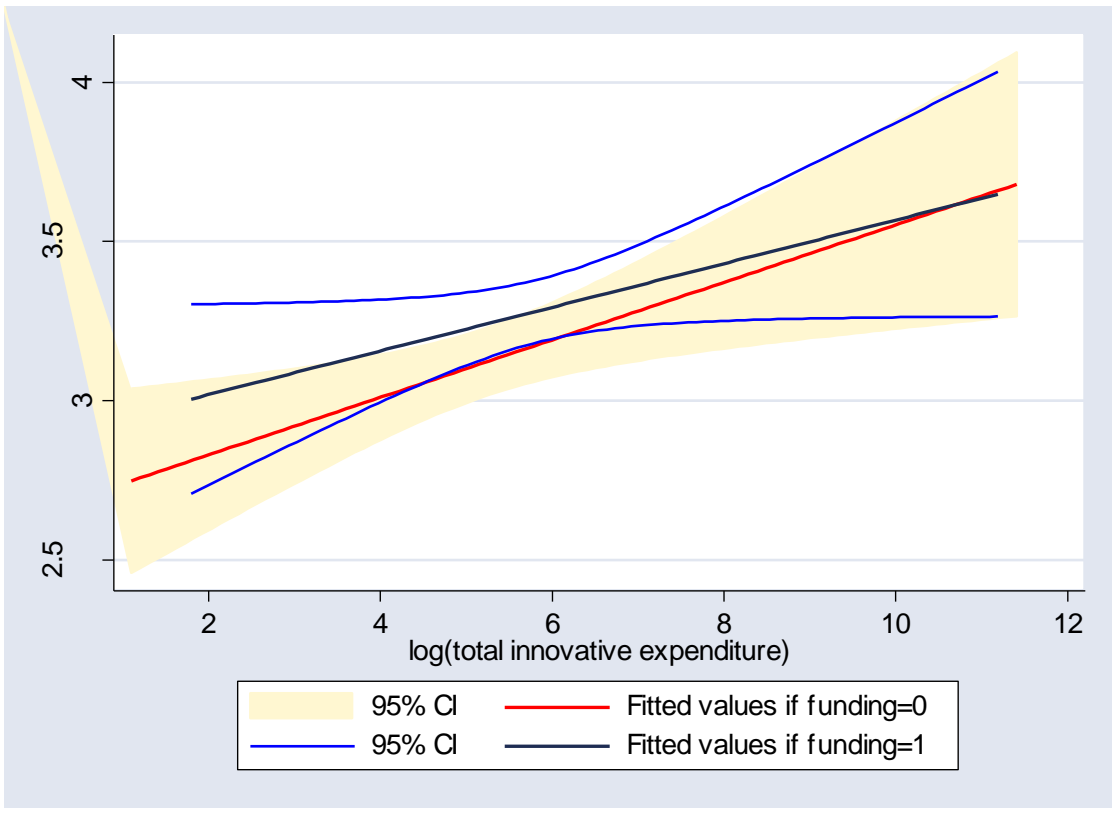


However, neither Figure 1 nor the previous descriptive statistics control for the possibility that this negative impact of the subsidy over pdtv may be driven either by selection biases or by $e x$ ante sources of firm heterogeneity. The following econometric setting is thus devoted to testing whether the negative impact of funding on innovative productivity persists once we have checked for the role that exogenous factors can play in differentiating the two subsamples of supported and non-supported firms ${ }^{13}$, as well as for the two sequential selection biases affecting our analysis (the first concerning the selection of the 2,855 innovative firms from the total 7,965 surveyed, and the second concerning the further selection of the 746 companies characterised by product innovation only).

In particular, while the first source of sample selection can be dealt with through a standard Heckman correction (i.e. by including the inverse Mills ratio obtained from a probit selection equation among the control variables), this is no longer the case when the second selection is considered. In fact, government intervention and the qualitative composition of the innovative output can be seen as simultaneous decisions, this rendering the selection of firms only engaged in product innovation potentially endogenous. A methodological solution allowing us to deal with all these issues simultaneously is developed in Section 4.

\section{The endogeneity problem: a bivariate switching solution}

The main difficulty affecting policy evaluation is the potential endogeneity of the subsidy, the assignment of which fails to satisfy the randomness property that should characterize pure social experiments. Indeed, as Lichtenberg (1984, p. 74) pointed out, "Federal contracts do not descend upon firms like manna from heaven"; an evaluation of the expected innovative outcome, by both the firm which has to decide whether to apply for the subsidy, and the public agency which must decide which projects to subsidise, is likely to

\footnotetext{
${ }^{13}$ See Table A1 in Appendix 1 for an exhaustive list of the observable factors introduced as controls, together with the other variables relevant to this study.
} 
precede the allocation process. This makes public funding an endogenous variable with respect to innovation itself.

The existing treatment evaluation literature offers alternative methodologies to deal with such potential endogeneity, however each of them imposes more or less restrictive conditions $^{14}$. In particular, these approaches rely on the hypothesis that depending on a set of observable explanatory factors $\mathrm{X}$, the alternative outcomes $y_{1}$ (with the treatment) and $y_{0}$ (without) are orthogonal to the treatment (D):

$$
y_{0}, y_{1} \perp D \mid X
$$

These approaches neglect the possibility that observable factors may simultaneously affect both the treatment (D) and the adopted performance measure (y). Simultaneous equation systems accomplish this aim, jointly taking into account the treatment assignment process and its outcome, i.e. checking whether the funding allocation process is partially determined by the same factors affecting the innovative process (endogeneity). In this framework, an endogenous dummy variable (D) becomes the dependent variable of a participation equation where the subsidy can be explained by the same factors affecting firms' innovative performance (see Busom, 2000). In other words, two different 'regimes' for the innovative performance are allowed, public support playing the role of endogenously switching firms from one regime to the other. Therefore, the resulting switching model can be written as:

$$
\begin{aligned}
& \left\{\begin{array}{l}
D_{i}^{*}=\alpha^{\prime} z_{i}+u_{i} ; \quad D_{i}=1 \text { if } D_{i}^{*}>0,0 \text { otherwise. } \\
y_{1 i}=\beta_{1}^{\prime} x_{i}+\varepsilon_{1 i} \quad \varepsilon_{1 i} \sim \mathrm{N}\left(0, \sigma_{11}\right) \\
y_{0 i}=\beta_{0}^{\prime} x_{i}+\varepsilon_{0 i} \quad \varepsilon_{0 i} \sim \mathrm{N}\left(0, \sigma_{00}\right)
\end{array}\right. \\
& \operatorname{corr}\left[u_{i}, \varepsilon_{1 i}\right]=\rho_{u 1} ; \quad \operatorname{corr}\left[u_{i}, \varepsilon_{0 i}\right]=\rho_{u 0}
\end{aligned}
$$

\footnotetext{
${ }^{14}$ See Cameron and Trivedi (2005) and Blundell and Costa Dias (2000) for a complete overview of the evaluation problem.
} 
where the set $\mathrm{z}$ of factors determining $\mathrm{D}$ partially overlaps the set $\mathrm{x}$ that explains the innovative outcome level y; the last row accounts for the likely correlation between the treatment-equation and the performance-equation error terms (endogeneity).

Such a simultaneous model fulfils two needs: firstly, it allows us to correct for funding endogeneity, producing consistent estimates of the performance equation (separately estimated on the two sub-samples of treated and non-treated firms); secondly, it solves the missing-data problem affecting the treatment evaluation literature; indeed, although we cannot directly observe how supported firms would have behaved had they not received the subsidy, we can nevertheless estimate the relevant model on the non-supported firms. The average treatment effect on treated firms can thus be computed consistently as:

$$
A T E T=E\left[y_{1 i} \mid x, D_{i}=1\right]-E\left[y_{0 i} \mid x, D_{i}=1\right]
$$

where the estimated coefficients obtained using the sub-sample of non-supported firms are applied to the supported ones, in order to achieve an estimate of the potential productivity the supported firms would have reached had they not received the subsidy.

This approach is here further developed in order to take into account a second source of endogeneity arising from the possible simultaneity between government intervention and the qualitative composition of the innovative output. Indeed, while receiving a subsidy is likely to foster one innovative typology at the expense of the others, it appears equally plausible that the qualitative composition of the innovation a firm has realised may affect the probability of receiving such a subsidy. This two-way simultaneous relationship should be taken into account when correcting for the selection of product innovators only. This is why we replace the participation equation identifying the switching in the standard endogenous switching models (eq. 2), with a bivariate model (eqs. 6 and 7). Therefore the estimated 'bivariate switching model' will be:

$$
\left\{\begin{array}{l}
\text { funding }_{i}^{*}=\alpha_{a}^{\prime} z_{a i}+u_{a i} ; \text { funding }=1 \text { if funding }{ }^{*}>0,0 \text { otherwise; } \\
P D T_{-} O N L Y_{i}^{*}=\alpha_{b}^{\prime} z_{b i}+u_{b i} ; P D T_{-} O N L Y_{i}=1 \text { if } P D T_{-} O N L Y_{i}^{*}>0,0 \text { otherwise. }
\end{array}\right.
$$




$$
p d t v_{i}= \begin{cases}\beta_{11}^{\prime} x_{i}+\varepsilon_{i} & \text { if funding=1 \& PDT_ONLY=1 } \\ \beta_{01}^{\prime} x_{i}+\varepsilon_{i} & \text { if funding=0 \& PDT_ONLY=1 } \\ \beta_{10}^{\prime} x_{i}+\varepsilon_{i} & \text { if funding=1 \& PDT_ONLY=0 } \\ \beta_{00}^{\prime} x_{i}+\varepsilon_{i} & \text { if funding=0 \& PDT_ONLY=0 }\end{cases}
$$

The first system thus accounts for the "double switching" (i.e. the joint probability of getting the subsidy and of engaging in product innovation only) that endogenously affects the productivity equation (second system). $\varepsilon, \mathrm{u}_{\mathrm{a}}$ and $\mathrm{u}_{\mathrm{b}}$ follow a trivariate normal distribution with variances $\sigma^{2}, 1$ and 1 respectively, and correlations $\rho_{\mathrm{ab}}, \rho_{\varepsilon \mathrm{a}}$ and $\rho_{\varepsilon \mathrm{b}}$ defined as follows:

$$
\rho_{a b}=\operatorname{corr}\left(u_{a}, u_{b}\right) ; \rho_{\varepsilon a}=\operatorname{corr}\left(u_{a}, \varepsilon\right) ; \rho_{\varepsilon b}=\operatorname{corr}\left(u_{b}, \varepsilon\right)
$$

The first two selection equations can thus be correlated with each other besides each being individually correlated to the main productivity equation; this fully incorporates the correction for the product-only sample selection into the bivariate switching model. Of course, once a bivariate (rather than a univariate) selection is implemented, four instead of just two different regimes are identified, accounting for the potential specificities that characterize each possible combination of the two 'switching' variables: $(1,1) ;(0,1) ;(1,0)$ and $(0,0)$.

From a computational point of view, four productivity equations should be estimated, each of them augmented by two additional terms (inverse Mills ratios) correcting for the double selection bias. Thus, for instance, focusing on the sub-sample identified by the combination (funding=1 \& PDT_ONLY=1), the estimated performance equation will be:

$$
p d t v_{i}=\beta_{11}^{\prime} x_{i}+\theta_{a} \lambda_{a}+\theta_{b} \lambda_{b}+\varepsilon_{i}
$$

where:

$\theta_{a}=\sigma \rho_{\varepsilon a} ; \theta_{b}=\sigma \rho_{\varepsilon b}$ 


$$
\begin{aligned}
& \lambda_{a}=\phi\left(w_{a}\right) \Phi\left[\left(w_{b}-\rho_{a b} \text { funding }\right) /\left(1-\rho_{a b}^{2}\right)^{1 / 2}\right] / \Phi_{2} \\
& \lambda_{b}=\phi\left(w_{b}\right) \Phi\left[\left(w_{a}-\rho_{a b} P D T_{-} O N L Y\right) /\left(1-\rho_{a b}^{2}\right)^{1 / 2}\right] / \Phi_{2}
\end{aligned}
$$

where $w_{a}=-\alpha_{a}^{\prime}$ funding, $w_{b}=-\alpha_{b}^{\prime} P D T \_O N L Y$ and $\rho_{a b}$ all being obtained from the bivariate probit estimates and then used to compute $\Phi_{2}=\Phi\left(w_{a}, w_{b}, \rho_{a b}\right)$.

The same procedure applies to the other three sub-samples. For our purposes, the relevant ATET will be:

$$
E\left[p d t v_{1 i} \mid x, \text { Funding }_{i}=1 \& P D T_{-} O N L Y=1\right]-E\left[p d t v_{0 i} \mid x, \text { Funding }_{i}=1 \& P D T \_O N L Y=1\right]
$$

where, following the same procedure adopted for the univariate endogenous switching model, the coefficients obtained on the sub-sample of non-supported product innovators will be applied to the supported ones in order to obtain an estimate of their potential productivity had they not received the subsidy (counterfactual).

\section{Empirical results}

The bivariate switching model presented in Section 4 is here estimated in order to properly test and measure the possible negative impact of the subsidy which emerged from the preliminary descriptive evidence reported in Table 1. In particular, four sequential steps have to be performed in order to estimate our model.

Firstly, the sample selection of 2,855 firms out of the 7,965 surveyed firms has to be taken into account by a standard Heckman procedure. Table 2 reports the results from the 
corresponding probit selection equation generating the inverse Mills ratio (lambda inn) which is included in all the following steps ${ }^{15}$.

Table 2: the probit selection equation

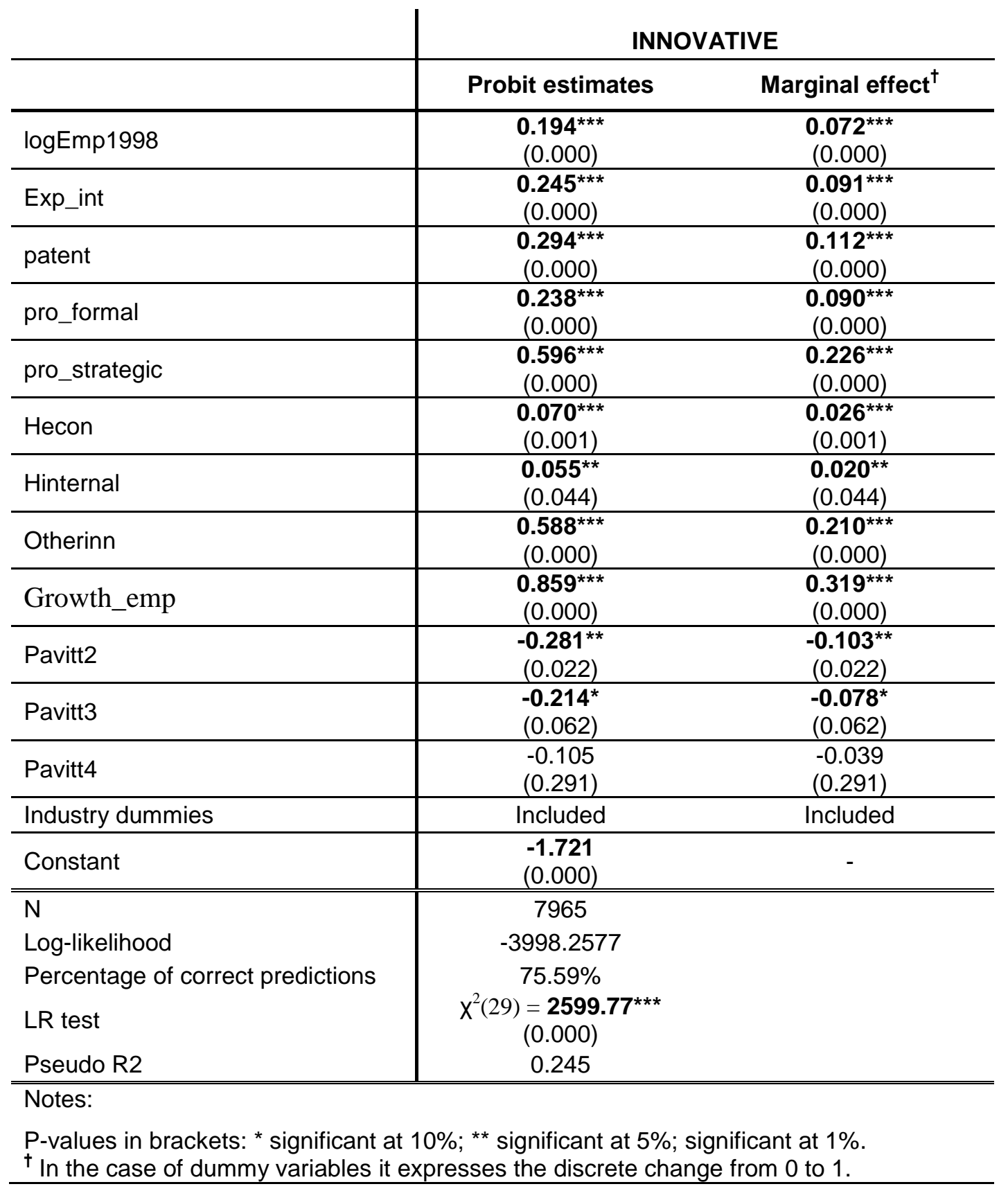

\footnotetext{
${ }^{15}$ While all the firm characteristics listed in Table A1 were initially included, only the significant regressors were retained in the final estimated probit specification.
} 
As can be seen (and not surprisingly), science-based, large, fast-growing and exporting firms are more likely to be innovative. By the same token, favourable appropriability conditions and complementary innovations also significantly affect the occurrence of technological innovation. Finally, a clearer perception of internal and financial obstacles to innovation is also positively correlated with the actual innovative effort.

Secondly, the probability of receiving public support and that of being product-only innovators were jointly estimated by means of a bivariate probit (eqs. 6 and 7).

Table 3: Bivariate switching model: the selection equations

\begin{tabular}{|c|c|c|}
\hline & Funding & PDT_ONLY \\
\hline Funding & - & $\begin{array}{c}-1.496^{\star \star *} \\
(0.000)\end{array}$ \\
\hline PDT_ONLY & $\begin{array}{c}-1.389^{* \star *} \\
(0.000)\end{array}$ & - \\
\hline $\log E m p(1998)$ & $\begin{array}{c}0.110 \\
(0.360) \\
\end{array}$ & $\begin{array}{l}-0.041 \\
(0.229) \\
\end{array}$ \\
\hline $\operatorname{logEmp1998\wedge 2}$ & $\begin{array}{l}-0.013 \\
(0.308) \\
\end{array}$ & - \\
\hline Avgbasic & 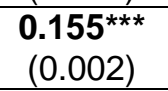 & $\begin{array}{l}\mathbf{0 . 0 9 7}^{\star \star} \\
(0.048)\end{array}$ \\
\hline Avgmkt & $\begin{array}{l}-0.025 \\
(0.498)\end{array}$ & - \\
\hline Exp_int & $\begin{array}{l}\mathbf{0 . 2 4 7}^{\star \star} \\
(0.050)\end{array}$ & $\begin{array}{l}\mathbf{0 . 2 3 2}^{*} \\
(0.065)\end{array}$ \\
\hline Mkt_extent & $\begin{array}{l}-0.014 \\
(0.557)\end{array}$ & - \\
\hline Gp & $\begin{array}{l}-0.042 \\
(0.551)\end{array}$ & - \\
\hline Ext_gp & $\begin{array}{l}-0.179^{*} \\
(0.091)\end{array}$ & - \\
\hline Cobasic & $\begin{array}{c}\mathbf{0 . 5 4 7}^{* \star * *} \\
(0.000)\end{array}$ & $\begin{array}{l}\mathbf{0 . 4 1 4}^{*} \\
(0.000)\end{array}$ \\
\hline e_flexibility & $\begin{array}{c}-0.028 \\
(0.244)\end{array}$ & - \\
\hline e_labour & - & $\begin{array}{c}-\mathbf{0 . 1 2 0} \\
(0.000)\end{array}$ \\
\hline pro_formal & - & $\begin{array}{c}0.055 \\
(0.458)\end{array}$ \\
\hline pro_strategic & - & $\begin{array}{l}-0.006 \\
(0.951)\end{array}$ \\
\hline tot_inn intensity & - & $\begin{array}{l}-0.420 \\
(0.237)\end{array}$ \\
\hline Growth_emp & - & $\begin{array}{l}-0.058 \\
(0.777)\end{array}$ \\
\hline
\end{tabular}




\begin{tabular}{|c|c|c|}
\hline Hecon & - & $\begin{array}{l}-0.001 \\
(0.983) \\
\end{array}$ \\
\hline lambda_inn & $\begin{array}{c}-0.088 \\
(0.274)\end{array}$ & $\begin{array}{l}-0.039 \\
(0.819)\end{array}$ \\
\hline Pavitt2 & $\begin{array}{l}-0.062 \\
(0.710)\end{array}$ & $\begin{array}{l}-0.024 \\
(0.895)\end{array}$ \\
\hline Pavitt3 & $\begin{array}{c}0.157 \\
(0.293)\end{array}$ & $\begin{array}{c}0.164 \\
(0.307)\end{array}$ \\
\hline Pavitt4 & $\begin{array}{l}\mathbf{0 . 2 6 2}^{\star \star} \\
(0.041)\end{array}$ & $\begin{array}{l}\mathbf{0 . 2 2 5}^{\star} \\
(0.093)\end{array}$ \\
\hline Strategies & - & Included \\
\hline Industry dummies & included & Included \\
\hline Constant & $\begin{array}{c}0.046 \\
(0.895)\end{array}$ & $\begin{array}{c}0.301 \\
(0.489) \\
\end{array}$ \\
\hline$\overline{\mathrm{N}}$ & \multicolumn{2}{|c|}{2855} \\
\hline Log-L & \multicolumn{2}{|c|}{-2684.432} \\
\hline Rho & \multicolumn{2}{|c|}{$\begin{array}{c}\mathbf{0 . 9 9 9 8}^{\star \star \star *} \\
(0.000)\end{array}$} \\
\hline
\end{tabular}

As can be seen in Table 3, the probability of obtaining the subsidy and of being a product-only innovator are inversely correlated (this is not surprising, given that the majority of the other 2,109 firms are more committed innovators, performing both product and process innovation). Of a firm's characteristics, the availability of scientific sources of information, export orientation, and cooperation with universities and/or research institutes all increase both the probability of being a product innovator and that of getting a public subsidy. Not surprisingly, the aim of lowering labour costs is negatively related to the likelihood of being product-only, in fact being the main purpose of process innovation.

Thirdly, the innovative productivity measure was separately regressed on the subsamples of firms identified by the switching variables, using the two inverse Mills ratios LAMBDA-A and LAMBDA-B from the bivariate probit estimates. However, given that our productivity measure is only available for the product-only innovators (see Section 3), only the first two classes $(1,1)$ and $(0,1)$ must be considered, comparing subsidized and nonsubsidized firms, conditional on them being product innovators. Results from this third step are reported in Table 4. 


\section{Table 4: Bivariate switching model: the main equations}

\begin{tabular}{|c|c|c|}
\hline Pdtv & $\begin{array}{c}\text { E(pdtv } \mid \text { funding }=1 \text { \& } \\
\text { PDT_ONLY=1) }\end{array}$ & $\begin{array}{c}\text { E(pdtv|funding }=0 \text { \& } \\
\text { PDT_ONLY =1) }\end{array}$ \\
\hline $\log E m p(2000)$ & $\begin{array}{c}0.595 \\
(0.492)\end{array}$ & $\begin{array}{c}0.776 \\
(0.471)\end{array}$ \\
\hline Exp_int & $\begin{array}{c}0.629 \\
(0.817) \\
\end{array}$ & $\begin{array}{c}3.764 \\
(0.287)\end{array}$ \\
\hline pdt_quality & $\begin{array}{l}\mathbf{2 . 6 2 3}^{\star \star *} \\
(0.000)\end{array}$ & $\begin{array}{l}3.247^{\star \star \star} \\
(0.000)\end{array}$ \\
\hline e_market & $\begin{array}{c}1.106 \\
(0.114) \\
\end{array}$ & $\begin{array}{l}1.616^{\star \star} \\
(0.063)\end{array}$ \\
\hline e_capacity & $\begin{array}{c}0.844 \\
(0.278) \\
\end{array}$ & $\begin{array}{l}-1.324 \\
(0.202)\end{array}$ \\
\hline mkt_novelty & $\begin{array}{l}2.301 \\
(0.160) \\
\end{array}$ & 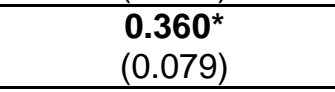 \\
\hline Otherinn & $\begin{array}{l}3.364 \\
(0.220) \\
\end{array}$ & $\begin{array}{c}1.964 \\
(0.580) \\
\end{array}$ \\
\hline pro_formal & $\begin{array}{c}0.953 \\
(0.599)\end{array}$ & $\begin{array}{l}-0.333 \\
(0.887)\end{array}$ \\
\hline pro_strategic & $\begin{array}{l}-0.045 \\
(0.986) \\
\end{array}$ & $\begin{array}{l}5.064^{\star} \\
(0.096)\end{array}$ \\
\hline Hinternal & $\begin{array}{c}1.080 \\
(0.265) \\
\end{array}$ & $\begin{array}{l}-0.979 \\
(0.368) \\
\end{array}$ \\
\hline Hecon & $\begin{array}{l}-0.168 \\
(0.834)\end{array}$ & $\begin{array}{l}-1.604^{\star} \\
(0.097)\end{array}$ \\
\hline lambda_inn & $\begin{array}{l}-0.516 \\
(0.932) \\
\end{array}$ & $\begin{array}{c}4.049 \\
(0.572) \\
\end{array}$ \\
\hline Pavitt2 & $\begin{array}{c}1.342 \\
(0.775) \\
\end{array}$ & $\begin{array}{l}-2.675 \\
(0.570) \\
\end{array}$ \\
\hline Pavitt3 & $\begin{array}{l}2.697 \\
(0.478) \\
\end{array}$ & $\begin{array}{l}-2.860 \\
(0.549) \\
\end{array}$ \\
\hline Pavitt4 & $\begin{array}{c}0.634 \\
(0.842) \\
\end{array}$ & $\begin{array}{l}-2.647 \\
(0.526) \\
\end{array}$ \\
\hline Strategies & Included & Included \\
\hline Industry dummies & Included & Included \\
\hline Constant & $\begin{array}{l}-4.126 \\
(0.792) \\
\end{array}$ & $\begin{array}{l}6.560 \\
(0.696) \\
\end{array}$ \\
\hline LAMBDA-A & $\begin{array}{l}-3.750 \\
(0.338) \\
\end{array}$ & $\begin{array}{c}3.923 \\
(0.630) \\
\end{array}$ \\
\hline LAMBDA-B & $\begin{array}{l}-3.305 \\
(0.406) \\
\end{array}$ & $\begin{array}{l}-5.991 \\
(0.508) \\
\end{array}$ \\
\hline $\begin{array}{l}\mathrm{N} \\
\mathrm{R} \text {-squared } \\
\text { F test } \\
\text { Log-likelihood }\end{array}$ & $\begin{array}{c}389 \\
0.2877 \\
F(50,338)=2.73^{\star \star \star *} \\
-1447.5735\end{array}$ & $\begin{array}{c}357 \\
0.2866 \\
F(50,306)=\mathbf{2 . 4 6} \\
-1380.4640 \\
\end{array}$ \\
\hline Notes: P-values ir & t 10\%; ** significant & cant at $1 \%$. \\
\hline
\end{tabular}


As can be seen, an above-average expectation of the innovative impact on the quality of the products emerges as the major driver of innovative productivity ${ }^{16}$.

Finally, turning our attention to the main purpose of this study, the average treatment effect of the subsidy (ATET) is computed in accordance with eq. 10. The results of this fourth step are reported in Table 5.

\section{Table 5: ATET from the bivariate switching model}

\begin{tabular}{|c|c|c|c|}
\hline $\begin{array}{l}\text { Supported } \\
\text { product- } \\
\text { only } \\
\text { innovators }\end{array}$ & $E\left[p d t v_{1 i} \mid x, F_{i}=1 \& P D T_{-} O N L Y=1\right]$ & $E\left[p d t v_{0 i} \mid x, F_{i}=1 \& P D T \_O N L Y=1\right]$ & $\begin{array}{l}\text { Treatment } \\
\text { effect } \\
\text { estimate } \\
(A-B)\end{array}$ \\
\hline$N=389$ & 10.091 & 15.043 & $\begin{array}{c}-4.953^{\star * *} \\
(0.000)\end{array}$ \\
\hline \multicolumn{4}{|c|}{ Notes: $p$-values in brackets; ${ }^{* * *}=1 \%$ significant. } \\
\hline
\end{tabular}

Far from being rejected, the efficiency loss highlighted by the preliminary descriptive statistics discussed in Section 3.2 (Table 1) above turns out to be even greater (and much more significant), once firms' characteristics and all the possible sources of sample selection and endogeneity have been taken into account fully.

Therefore, our suspicion of an efficiency loss being associated with government intervention is strongly confirmed: far from 'doing better' as a result of the subsidy, supported firms turn out to increase both their innovation inputs and their innovation outputs, but the latter effect is less than proportional with respect to the former.

\section{Conclusions}

Drawing on a standard evaluation literature mainly aimed at estimating the additional effect of subsidies on either firms' innovative inputs or outputs only, this paper has tried to move one step further, combining the two dimensions of innovative performance into one single variable. In particular, using data from the third Italian Community Innovation Survey,

\footnotetext{
${ }^{16}$ This is not surprising, since an innovation able to increase the quality of the final products significantly is likely to increase the share of turnover due to innovative products and hence our pdtv measure.
} 
a new variable has been constructed, expressing how many euros of innovative sales a firm realises for each euro spent on innovative inputs (innovative productivity). The rationale behind this choice was to explore whether supported innovative firms are really doing better, not just more, than their non-supported counterparts.

Once cleared of any source of firm heterogeneity due to different sources of sample selection, as well as being checked for possible simultaneity between public support and the qualitative composition of a firm's innovative activity (bivariate switching model), the impact of the subsidy turns out to be negative. Despite it being current common practice to publicly support innovation, government intervention actually appears to induce higher expenses, while the efficiency associated with such innovative expenditures is affected negatively, at least as far as product innovations are concerned.

The limitations of the adopted dataset, comprising a lack of information about the magnitude and typology of the subsidy, make it difficult to provide an explanation for the efficiency loss we found. Tentatively, we suggest the negative impact of public support on firms' innovative productivity may be a special case of the lower efficiency that seems to characterise externally-funded innovative expenditures with respect to corresponding privately-funded expenditures (see Fazzari et al., 1988; Hubbard, 1998 and Hall, 2002). However, further studies are needed, both to test again our results and to confirm this possible interpretative view. 


\section{Appendix}

\section{Table A1: List and definitions of the dependent and explanatory variables}

\section{Dependent variables}

\begin{tabular}{ll}
\hline funding & $\begin{array}{l}\text { Dummy }=1 \text { if the firm has received a financial subsidy in support } \\
\text { of innovation, } 0 \text { otherwise }\end{array}$ \\
\hline Pdtv & $\begin{array}{l}\text { Innovative productivity (total innovative sales/total innovative } \\
\text { expenditure) }\end{array}$ \\
\hline INNOVATIVE & $\begin{array}{l}\text { Dummy }=1 \text { if the firm invested in innovative activities in the } \\
\text { period } 1998-2000 \text { and has realised a product and/or a process } \\
\text { innovation, or it has undertaken an innovative project (later } \\
\left.\text { dropped or still to be completed at December } 31^{\text {st }}, 2000\right)\end{array}$ \\
\hline PDT_ONLY & Dummy $=1$ if the firm has realised product innovations only \\
\hline
\end{tabular}

\section{Firm characteristics and other controls}

\begin{tabular}{ll}
\hline $\begin{array}{l}\text { logEmp1998 } \\
\text { (logEmp2000) }\end{array}$ & $\begin{array}{l}\text { Logarithmic transformation of firm's employees at December } 31^{\text {st }}, \\
1998(2000)\end{array}$ \\
\hline Growth_emp & Employees - rate of growth (1998-2000) \\
\hline Exp_int & Export intensity (turnover from export/turnover) in 2000. \\
\hline mkt_extent & $\begin{array}{l}\text { Prevailing (geographical) market extent, ranging from 0 (local) to } \\
7 \text { (Extra-UE) }\end{array}$ \\
\hline Gp & $\begin{array}{l}\text { Belonging to an industrial group (dummy variable) } \\
\text { Belonging to an industrial group with foreign headquarters } \\
\text { (dummy variable) }\end{array}$ \\
\hline ext_gp & $\begin{array}{l}\text { 23 Industry dummies defined according to the two-digit ATECO } \\
\text { 91 classification }\end{array}$ \\
\hline Industry dummies & $\begin{array}{l}\text { Dummies mapping the three-digit ATECO 91 codes onto the four } \\
\text { categories identified by Pavitt's (1984) taxonomy: } \\
\text { pavitt1=1 for science-based firms, 0 otherwise; } \\
\text { pavitt2=1 for supplier-dominated firms, } 0 \text { otherwise; } \\
\text { pavitt3=1 for scale-intensive firms, 0 otherwise; } \\
\text { pavitt4=1 for specialized suppliers, 0 otherwise }\end{array}$ \\
Pavitt1-Pavitt4 & $\begin{array}{l}\text { Inverse Mills ratio correcting for the selection of innovative firms } \\
\text { only }\end{array}$ \\
\hline lambda_inn &
\end{tabular}

\section{Innovation-relevant information}

$\log ($ tot_exp)

tot_inn intensity
Logarithmic transformation of total innovative expenditures in 2000

Intensity of total innovative expenditures in 2000 (total innovative expenditure/turnover) 
Turninn

\begin{tabular}{|c|c|}
\hline Avgbasic & $\begin{array}{l}\text { Average importance of basic sources of information (universities, } \\
\text { research institutes, conferences) for the innovative process: from } 0 \\
\text { to } 3 \\
\text { Average importance of market sources of information } \\
\text { (competitors, customers, suppliers) for the innovative process: } \\
\text { from } 0 \text { to } 3\end{array}$ \\
\hline Cobasic & $\begin{array}{l}\text { Cooperation agreements with universities and/or research institutes } \\
\text { (dummy variable) }\end{array}$ \\
\hline e_market & $\begin{array}{l}\text { Innovation addressed to entering new markets or raising a firm's } \\
\text { market share: from } 0 \text { to } 3\end{array}$ \\
\hline e_capacity & Innovation addressed to raising production capacity: from 0 to 3 \\
\hline e_flexibility & Innovation addressed to raising production flexibility: from 0 to 3 \\
\hline e_labour & Innovation addressed to lowering the cost of labour: from 0 to 3 \\
\hline Hinternal & $\begin{array}{l}\text { Average relevance of internal hurdles (lack of information, lack of } \\
\text { skilled personnel, organizational rigidities) in hampering } \\
\text { innovation (1998-2000): from } 0 \text { to } 3\end{array}$ \\
\hline Hecon & $\begin{array}{l}\text { Average relevance of financial hurdles (economic costs and/or } \\
\text { risks too high, no sources of financial support) in hampering } \\
\text { innovation (1998-2000): from } 0 \text { to } 3\end{array}$ \\
\hline pro_formal & $\begin{array}{l}\text { Dummy }=1 \text { if patents, copyright or registration of brands are } \\
\text { perceived by the firm as useful ways to increase appropriability }\end{array}$ \\
\hline pro_strategic & $\begin{array}{l}\text { Dummy = } 1 \text { if secrecy, complexity or lead time are perceived by } \\
\text { the firm as useful ways to increase appropriability }\end{array}$ \\
\hline patent & $\begin{array}{l}\text { Dummy }=1 \text { if the firm registered at least one patent over the } \\
\text { period } 1998-2000\end{array}$ \\
\hline pdt_quality & Evaluation of the innovative effect on product quality: from 0 to 3 \\
\hline mkt_novelty & Dummy $=1$ if product innovations are new to the market \\
\hline Otherinn & $\begin{array}{l}\text { Dummy }=1 \text { if the firm realised managerial, strategic and/or } \\
\text { organizational innovations }(1998-2000)\end{array}$ \\
\hline Strategies & $\begin{array}{l}\text { Sixteen innovative strategy dummies covering all the possible } \\
\text { combinations of the four main innovative inputs firms can choose } \\
\text { from: internal R\&D; external R\&D; embodied technological } \\
\text { acquisition in innovative machinery; disembodied technological } \\
\text { acquisition such as licences }\end{array}$ \\
\hline
\end{tabular}




\section{REFERENCES}

Arrow K. (1962): Economic Welfare and the Allocation of Resources for Innovation. In Nelson R. (Ed.): The Rate and Direction of Economic Activity, Princeton University Press, New York.

Bérubé C., Mohnen P. (2009). Are Firms that Receive R\&D Subsidies More Innovative?, Canadian Journal of Economics, 42, 206-225,

Blundell R., Costa Dias M. (2000): Evaluation Methods for Non-experimental Data, Fiscal Studies, 21, 427-468.

Branstetter L., Sakakibara M. (1998): Japanese Research Consortia: A Microeconometric Analysis of Industrial Policy, Journal of Industrial Economics, 46, 207-233.

Busom I. (2000): An Empirical Evaluation of the Effects of R\&D Subsidies, Economics of Innovation and New Technology, 9, 111-148.

Cameron, A.C., Trivedi, P.K. (2005): Microeconometrics, Methods and Applications. Cambridge University Press, Cambridge.

Capron H., Van Pottelsbergue B. (1997): Public Support to Business R\&D: a Survey and Some New Quantitative Evidence. In OECD: Policy Evaluation in Innovation and Technology. Towards Best Practices. Paris.

Cohen L., Noll R. (1991): The Technology Pork Barrel. The Brookings Institution, Washington D.C.

Conte A., Vivarelli, M. (2005): One or Many Knowledge Production Functions?Mapping Innovative Activity Using Microdata. IZA Discussion Paper No. 1878, Institute for the Study of Labour. Bonn.

Czarnitzki D. (2002): Research and Development: Financial Constraints and the Role of Public Funding for Small And Medium-sized Enterprises. ZEW Discussion Paper Series, N. 02-74, ZEW. Mannheim.

Fazzari S., Hubbard R. G., Petersen B. C. (1988): Financing Constraints and Corporate Investment, NBER Working Papers 2387, National Bureau of Economic Research. Cambridge (Mass).

García-Quevedo, J. (2004): Do Public Subsidies Complement Business R\&D? A Metaanalysis of the Econometric Evidence, Kyklos, 57, 87-102.

Garcia A., Mohnen P. (2010): Impact of government support on $R \& D$ and innovation, UNU-MERIT Working Paper 2010-034, UNU-MERIT. Maastricht.

Gonzáles X., Jaumandreu J., Pazó C. (2005): Barriers to Innovation and Subsidy Effectiveness, RAND Journal of Economics, 36, 930-949.

Griliches Z. (1992). The Search for R\&D Spillovers, Scandinavian Journal of 
Economics, 94, S29-S47.

Hall B. (1991): Firm-level Investment with Liquidity Constraints: What Can the Euler Equations Tell Us? Mimeo, UC Berkeley, U.S.

Hall B. (1996): The Private and Social Returns to Research and Development. In Smith B., Barfield C. (Eds.): Technology, $R \& D$, and the Economy, Brookings Institution and AEI, Washington DC, 140-162.

Hall B. (2002): The Financing of Research and Development, Oxford Review of Economic Policy, 18, 35-51.

Heckman J. (1979): Sample Selection as a Specification Error, Econometrica, 47, 153161.

Hubbard R. G. (1998): Capital-Market Imperfections and Investment, Journal of Economic Literature, 36, 193-225.

ISTAT (2004): Statistiche sull' Innovazione delle Imprese, Settore Industria, Anni 19982000. ISTAT, Roma.

Lach S. (2002): Do R\&D Subsidies Stimulate or Displace Private R\&D? Evidence from Israel, Journal of Industrial Economics, 50, 369-390.

Leland H. E., Pyle D. H. (1977): Informational Asymmetries, Financial Structure, and Financial Intermediation, Journal of Finance, 32, 371-387.

Lichtenberg, F. (1984): The Relationship between Federal Contract R\&D and Company R\&D, American Economic Review Papers and Proceedings, 74, 73-78.

Pavitt K. (1984): Sectoral Patterns of Technical Change: Towards a Taxonomy and a Theory, Research Policy, 13, 343-373.

Piga, C.A., Vivarelli, M. (2003): Sample Selection in Estimating the Determinants of Cooperative R\&D. Applied Economics Letters, 10, 243-246.

Rubin D. B. (1978): Bayesian Inference for Causal Effects, Annals of Statistics, 6, 34-58.

Wallsten S. J. (2000): The Effects of Government-Industry R\&D Programs on Private R\&D: The Case of the Small Business Innovation Research Program, RAND Journal of Economics, 31, 82-100. 